\title{
The 2011-2012 El Hierro submarine eruption: a challenge of geochemical and thermal imaging for volcano monitoring
}

\author{
NEMESIO M. PÉREZ 1,2 \\ ${ }^{1}$ Instituto Volcanológico de Canarias (INVOLCAN), 38400 Puerto de la Cruz, Tenerife, Canary Islands, SPAIN \\ ${ }^{2}$ Instituto Tecnológico y de Energías Renovables (ITER), 38611 Granadilla de Abona, Tenerife, Canary Islands, SPAIN \\ e-mail: nperez@iter.es
}

\begin{abstract}
A shallow submarine eruption occurred between October 12, 2011 and March 5, 2012 about $2 \mathrm{~km}$ off the southern coast of El Hierro, the youngest and smallest of the seven major islands of the Canarian archipelago. This submarine eruption rose from a depth of 363 meters and finally reached 89 meters bsl and provided us a unique chance to study a variety of precursory signals before the eruption as well as to evaluate for the very first time magma emission rates from a shallow submarine eruption using airborne thermal imaging.
\end{abstract}

\section{INTRODUCTION}

El Hierro is the smallest and most south-western Island of the Canarian archipelago with an area of $278 \mathrm{~km}^{2}$ (Figure 1a). It represents the summit of a volcanic shield elevating from the surrounding seafloor at depth of $4,000 \mathrm{~m}$ to up to $1,501 \mathrm{~m}$ above sea level. El Hierro Island is the youngest in the Canarian archipelago, with the oldest subaerial rocks dated at 1.12 Ma (Guillou et al., 1996). Recent volcanic activity occurred mainly along the three volcanic ridges bearing $\mathrm{NE}, \mathrm{S}$ and $\mathrm{SW}$ with respect to the center of the island. Before the 2011-2012 submarine eruption and for the last 500 years, Hernández Pacheco (1982) reported a single volcanic eruption during 1793 at Lomo Negro, although its occurrence is questionable (carbon-14 indirect dating) and most probably consisted of an offshore eruption (Romero and Guillén, 2012). In the last $37 \mathrm{ka}$, El Hierro has been covered with lavas erupted in the last stage of its volcanic evolution, and deep embayment has been produced by giant landslides between the three rift zones. The most recent one was the El Golfo failure on the northwest flank of El Hierro, which took place approximately 15 ka ago (Masson, 1996). Stroncik et al. (2009) carried out a thermobarometric and petrologic study on basanites erupted from young volcanic cones along the submarine portions of the three El Hierro rift zones to reconstruct magma plumbing and storage beneath the island. They concluded that small, intermittent magma chambers might be a common feature of oceanic islands fed by plumes with relatively low magma fluxes, which results in limited and discontinuous magma supply.

After hundreds of years of repose, on October 12, 2011, an eruption of El Hierro occurring under water was detected by visual observations off the coast of El Hierro, about $2 \mathrm{~km}$ south of the small village of La Restinga. This submarine volcanic eruption was preceded by (i) an unusual increase of seismicity 


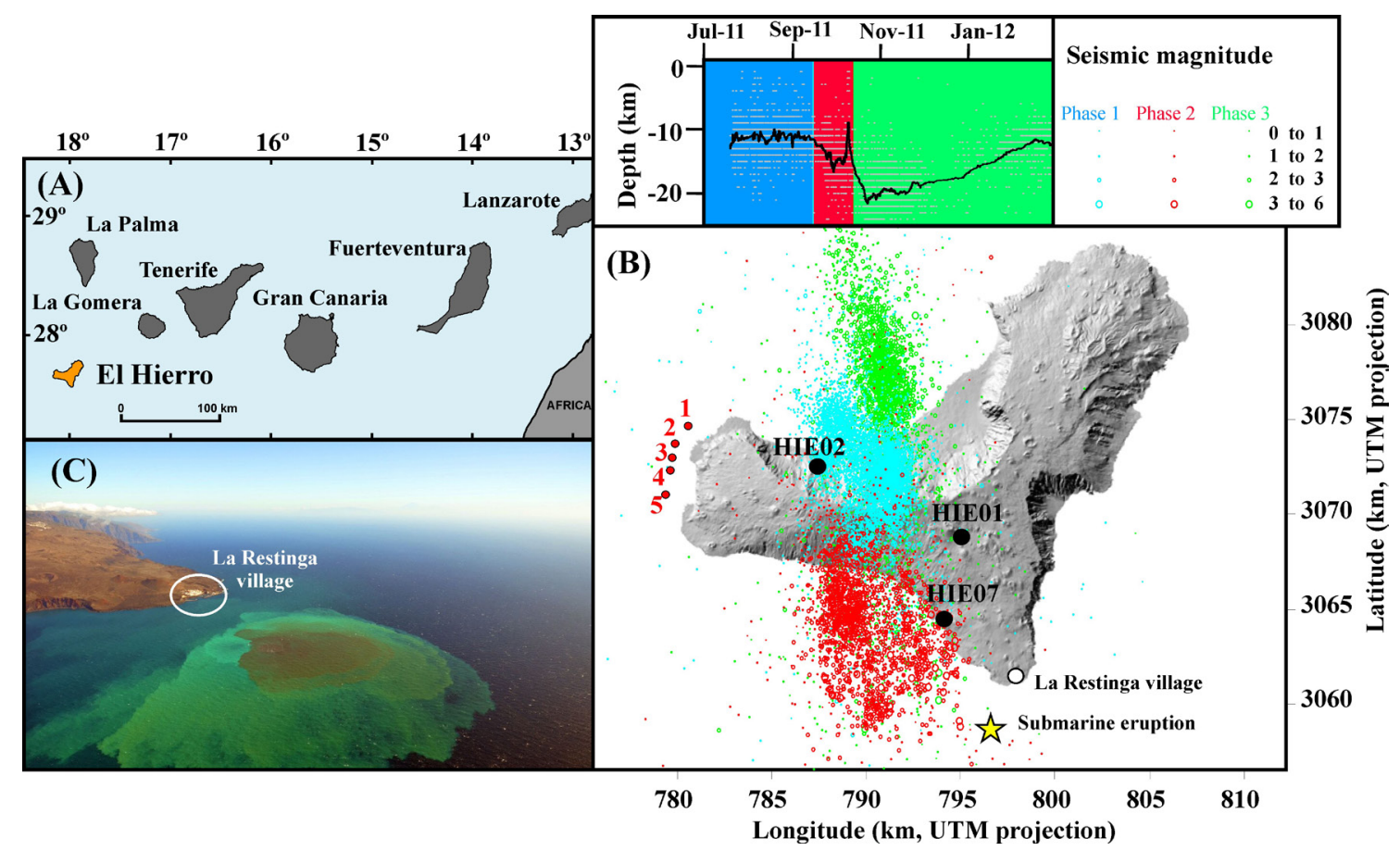

Figure 1. A: Geographic location of El Hierro Island (Canary Islands, Spain). B: Epicenter locations of 12,178 seismic events recorded until 9 February 2012. Different phases of seismicity described by Ibáñez et al. (2012) are displayed in blue, red, and green. Temporal evolution of hypocentral depth of earthquakes is depicted by 100 event moving average (black line). Star indicates location of submarine eruption (UTM-Universal Transverse Mercator). Black dots indicate location of geochemical stations and red dots location of submarine plumes. C: Water discoloration south of La Restinga produced by submarine eruption.

(more than 9000 seismic events) recorded by the National Geographical Institute of Spain (IGN) since July 19, 2011 (Figure 1b), (ii) a significant ground deformation detected by the seven-GPS network (Nagoya University-ITERGRAFCAN) deployed at El Hierro (Sagiya et al. 2012), and (iii) by significant changes in the volcanic gas emissions, detected both by the continuous geochemical monitoring network (Pérez et al. 2012; Padilla et al. 2013) and by discrete geochemical surveys of diffusive helium emission and ${ }^{3} \mathrm{He} /{ }^{4} \mathrm{He}$ ratio data of dissolved gases in groundwater (Padrón et al. 2013) and diffuse $\mathrm{CO}_{2}$ emissions (Melián et al. 2014). From the starts of the submarine eruption, a large area of discolored water in the sea was observed most of the time (Figure 1c), from light green to dark brown color, caused by chemical interaction of seawater with the intensely discharging of high-temperature volcanic hydrothermal fluids plus magmatic gases. Throughout December 2011 and January 2012, the seismicity gradually declined and the eruption subsided, with earthquake rates returning to low levels, close to background, and tremor considerably reduced in amplitude (Ibáñez et al. 2012). On March 5, 2012, the Scientific Committee stated that the submarine eruption was over, but the volcanic process that started on mid July 2011 had not finished (Smithsonian report, 29 February to 6 March 2012).

In fact, since June 2012, a new episode of volcanoseismic unrest started, with a high rate of seismicity occurring from June 25 to July 13. During this period, more than a thousand volcano-tectonic earthquakes occurred west of El Hierro Island (Figure 1b). This increase of seismic activity was sudden and seemed to be triggered by a first earthquake of magnitude 3.2, located by the IGN seismic network at 21:26:01 (local time) with coordinates N27.7897 andW18.0642 at a depth of $20 \mathrm{~km}$. Seismicity was characterized by a larger number of seismic events with magnitude $>2.5$ (715 events in 21 days) compared to the period July 2011 to March 2012 (748 events in 230 days), the largest with magnitude 4.4 occurred on July 2, 2011. García-Yeguas et al., 2014, reported 3D images of the structure beneath El Hierro Island from a seismic tomography study, which showed a strong lowvelocity anomaly beneath the west offshore area of the island.

Submarine volcanoes are widespread on the sea floor but are mainly concentrated along the convergent and divergent margins of tectonic plates and at hot spots (Smith and Jordan 1987; Smith and Cann 1992). Due to the water depths where 
this volcanic activity occurs, monitoring submarine volcanic eruptions is a very difficult task. However, when a submarine eruption occurs at shallow depths (tens to few hundred meters), there is an excellent opportunity to monitor and study it. Nowadays, knowledge about submarine eruptions is increasing rapidly, and new techniques allow detection and observation of signals of submarine volcanic unrest.

\section{GEOCHEMICAL MONITORING}

\section{Continuous soil $\mathrm{CO}_{2}$ and $\mathrm{H}_{2} \mathrm{~S}$ monitoring}

Observing changes in the composition and discharge rates of volcanic gases is an important part of volcanic monitoring programs, because some gases released by progressive depressurization of magma during ascent are highly mobile and reach the surface well before their parental magma (Hernández et al., 2001; Granieri et al., 2006). Among volcanic gas studies at volcanoes, diffuse $\mathrm{CO}_{2}$ degassing phenomena, has played an important role owing to the special characteristics of $\mathrm{CO}_{2}$ : it is the major gas species after water vapor in both volcanic fluids and magmas and it is an effective tracer of sub-surface magma degassing (Gerlach and Graeber, 1985). In contrast to these studies on $\mathrm{CO}_{2}$, very few studies have focused on diffuse $\mathrm{H}_{2} \mathrm{~S}$ measurements in volcanic areas, as the gas is much harder to detect.

On September 25, 2003, a geochemical station (HIE01) was installed at Llanos de Guillén, in the interception center of the three volcanic rifts of El Hierro Island (Lat.: N 27\%42'58.2"; Long.: W $18^{\circ} 01^{\prime} 8.8^{\prime \prime}$ ), where previous $\mathrm{CO}_{2}$ efflux surveys indicated one of the highest $\mathrm{CO}_{2}$ efflux values measured in El Hierro Island during inter-eruptive periods. The second automatic geochemical station (HIE07) was installed near Tacorón cove, south El Hierro Island (Latitude: N 27 $40^{\prime} 56.9^{\prime \prime}$; Longitude: W $\left.8^{\circ} 1^{\prime} 44.5^{\prime \prime}\right)$ on October 7, 2011, almost one week before the starts of the submarine eruption. Both stations measured hourly $\mathrm{CO}_{2}$ and $\mathrm{H}_{2} \mathrm{~S}$ efflux, and $\mathrm{CO}_{2}$ and $\mathrm{H}_{2} \mathrm{~S}$ air concentrations. To filter the possible influence of external parameters in the endogenous $\mathrm{CO}_{2}$ and $\mathrm{H}_{2} \mathrm{~S}$ emissions, soil water content and temperature at a $40-\mathrm{cm}$ depth and atmospheric parameters (wind speed and direction, air temperature and humidity, rainfall, and barometric pressure $1 \mathrm{~m}$ above the ground), were recorded simultaneously.

During the period of study, the observed $\mathrm{CO}_{2}$ efflux values recorded at HIE01 ranged from non-
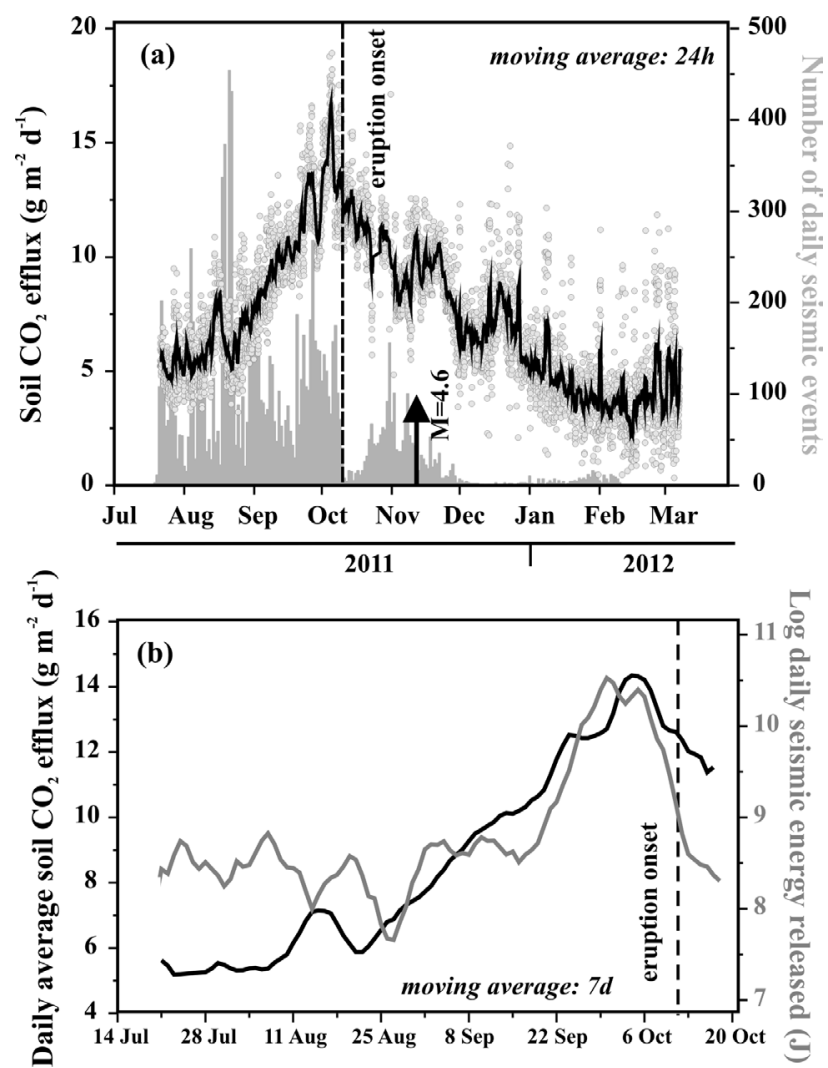

Figure 2. (a) Time series of the measured $\mathrm{CO}_{2}$ efflux during the 2011-2012 period of volcanic unrest at HIE01; moving average is shown as well as the recorded seismicity during the same time period by the seismic network of IGN. (b) Daily average $\mathrm{CO}_{2}$ efflux measured at HIE01 and daily seismic energy released during the geochemical precursory time window.

detectable values to $18.9 \mathrm{gm}^{-2} \mathrm{~d}^{-1}$ with an average of $8.0 \mathrm{gm}^{-2} \mathrm{~d}^{-1}$ (Figure 2a). From the beginning of the observation time to August 10, 2011, soil $\mathrm{CO}_{2}$ efflux time series was characterized by a low variance with $\mathrm{CO}_{2}$ efflux values showing a median value of 5.6 $\mathrm{gm}^{-2} \mathrm{~d}^{-1}$. From August 10 to 17 , a sharp increase on $\mathrm{CO}_{2}$ efflux rate occurred, reaching a value of $11 \mathrm{gm}^{-}$ ${ }^{2} \mathrm{~d}^{-1}$. This peak in $\mathrm{CO}_{2}$ efflux was observed one day before the most intense seismic activity in terms of number of seismic events during the period of study, with 1,863 earthquakes occurring between August 18 and August 23. Later, from August 23 to October 5, a continuous increase in the $\mathrm{CO}_{2}$ efflux time series was observed, culminating in the maximum $\mathrm{CO}_{2}$ efflux measured during this study, $18.9 \mathrm{gm}^{-2} \mathrm{~d}^{-1}$. The greatest rate of increase occurred one week before the initiation of the submarine eruption south of El Hierro Island. Figure $2 \mathrm{~b}$ shows the daily average $\mathrm{CO}_{2}$ efflux and the daily released seismic energy between the mid-July and October 20, the time of the observed precursory $\mathrm{CO}_{2}$ efflux signal at HIE01. 


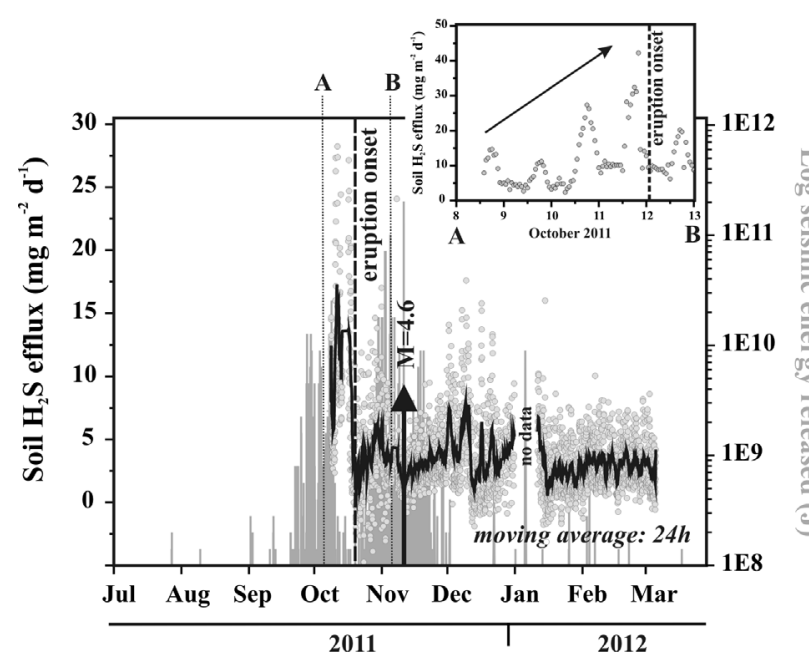

Figure 3. Time series of the measured $\mathrm{H}_{2} \mathrm{~S}$ efflux recorded during the period October 8, 2011-March 5, 2012, at HIE07; moving average is shown as well as the recorded seismicity during the same time period by the seismic network of IGN.

Both time series show a good temporal correlation, which supports the hypothesis that there was a precursory diffuse $\mathrm{CO}_{2}$ efflux signal before the onset of the submarine eruption. At HIE07, a sharp increase in the $\mathrm{H}_{2} \mathrm{~S}$ diffuse emissions was observed between the installation on October 7, 2011, and the eruption onset, increasing from $<2$ to $42 \mathrm{mgm}^{-2} \mathrm{~d}^{-1}$ (Figure 3).

The observed increasing rate of diffuse emission at HIE01 likely suggested that ascent of magma occurred in a regular rate, but this observation contradicts the hypocenters of the seismicity time series observed along the crisis, which did not show such a regular behavior, as it should has been expected. The increasing on pressure of the magmatic gases might have driven the magma movement to the surface, being reflected as an increase of $\mathrm{CO}_{2}$ diffuse emission at HIE01. The observed temporal change on the $\mathrm{CO}_{2}$ diffuse emission at HIE01 before the eruption onset has proven as a good indicator of changes of energy of the magmatic plumbing system at depth, which triggered the ascent of magma towards surface.

\section{Continuous soil radon monitoring}

With the aim of providing a multiparametric geochemical approach, in August of 2005, two geochemical stations (HIE02 and HIE03) were installed at HIE02 (San Simon well; Figure 1b, N27 45.28'; W18 6.41'; 26ma.s.1.), and at HIE03 (La Restinga Village; Figure 1b, N2 $7^{\circ} 38.54^{\prime}$; W1 17 $58.97^{\prime}$; 30ma.s.1.), to measure ${ }^{222} \mathrm{Rn}$ and ${ }^{220} \mathrm{Rn}$ activities by means of a SARAD RTM-2010-2 radon monitors during a period of volcanic quiescence. Time series

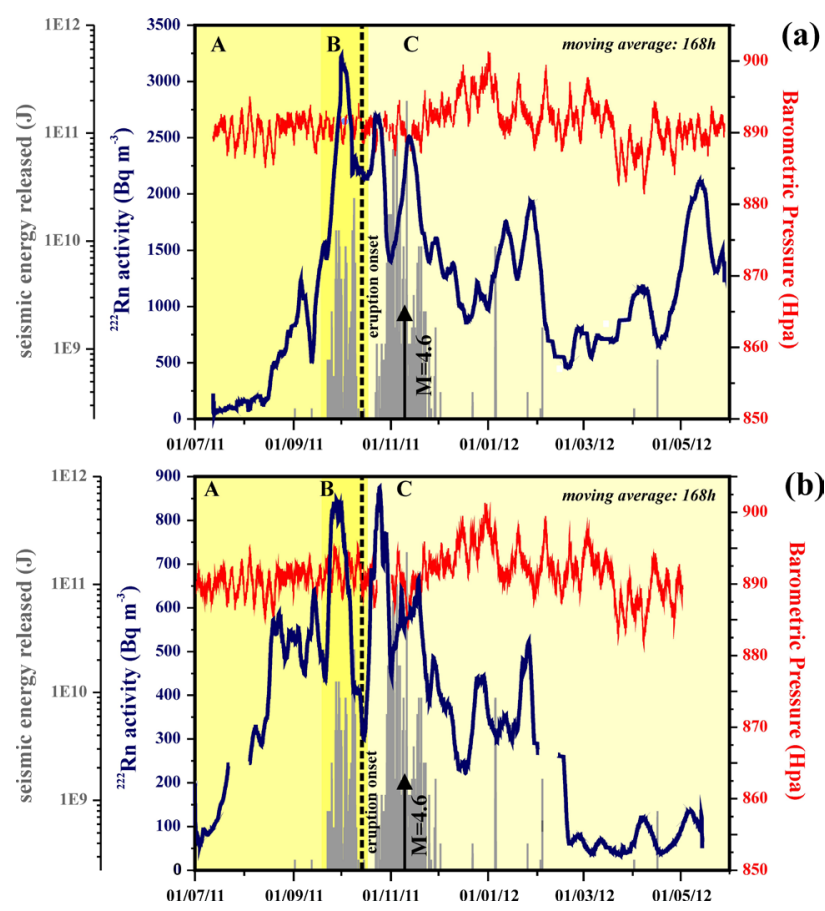

Figure 4. Temporal plot of the moving average of ${ }^{222} \mathrm{Rn}$ time series measured at HIE02 (a) and HIE03 (b) geochemical stations station (Blue line), respectively. At each graph, red line indicates barometric pressure measured at HIE01 station. Light grey bars show the seismic energy release during the study period. The radon time series was divided into three segments (A, B and C) according to distinct regimes of earthquake occurrence (Ibañez et al., 2012).

of soil ${ }^{222} \mathrm{Rn}$ showed variations ranging between 0 to 16,459 $\mathrm{Bqm}^{-3}$, and 0 to $1,646 \mathrm{Bqm}^{-3}$ for HIE02 and HIE03 geochemical stations, respectively. Figure $4 \mathrm{a}$ and $4 \mathrm{~b}$ show the $168 \mathrm{~h}$ moving average of soil ${ }^{222} \mathrm{Rn}$ measured at HIE02 and HIE03 stations, respectively, together with hourly barometric pressure and daily released seismic energy. Phases A, B and C (Ibañez et al., 2012) are also shown. During most of phase $\mathrm{A}$, radon degassing is mainly characterized by a deep magma contribution reflecting the initial intrusion of magma from the upper mantle into the crust, with the highest deep contribution occurring at the end of phase A, just before the start of the first significant seismic energy release (phase B) which ended in the submarine eruption. From September 21 to October 10, 2011 (phase B), just before the eruption onset on October 12 , highest ${ }^{222} \mathrm{Rn}$ and ${ }^{220} \mathrm{Rn}$ activities were recorded during all observation periods, indicating strong deep and shallow contributions due to the magma movement to the surface. Finally, from October 11, 2011, (phase C), when the largest magnitude earthquakes were recorded reflecting crustal relaxation around the magma reservoir that 
had fed the submarine eruption, the shallow degassing component for radon was predominant.

As soil gas radon activities and soil $\mathrm{CO}_{2}$ increased prior to the occurrence of major seismic volcanic events and prior to the eruption onset, these gases can be efficiently used as an initial warning sign of the pressurization of magma beneath El Hierro Island, together with other geochemical and geophysical data.

\section{Diffusive helium emission surveys}

In summer 2003, the first diffusive helium emission survey of El Hierro Island was performed by analyzing the helium content of soil gas at 473 sampling points located homogeneously across the entire surface of the island. Since the beginning of the recent 2011-2012 seismic-volcanic unrest period at El Hierro, another 14 helium emission surveys have been carried out, with 601 sampling sites. Simultaneously, the ${ }^{3} \mathrm{He} /{ }^{4} \mathrm{He}$ ratio in groundwater has been measured regularly at HIE02 (Figure 1b). Sampling of dissolved gas from HIE02 for ${ }^{3} \mathrm{He} /{ }^{4} \mathrm{He}$ ratio was performed regularly from July, 2011, and analyzed at the lab facilities of the Geochemical Research Center of The University of Tokyo. The determination of helium isotopic ratios as well as ${ }^{4} \mathrm{He}$ and ${ }^{20} \mathrm{Ne}$ concentrations is done following the method described by Sumino et al. (2001).

Diffusive helium emissions in the 2003 survey amounted for $9 \pm 1 \mathrm{kgd}^{-1}$ for the entire area of El Hierro Island. This value is interpreted as the background helium emission of El Hierro Island in a period of volcanic quiescence, and it is depicted in Figure 5a, which shows both diffusive helium emissions for the entire island and the corrected ${ }^{3} \mathrm{He} /{ }^{4} \mathrm{He}$ ratio for the dissolved gases in the San Simon waters together with the seismic energy released 9 February 2012. By mid-September, a drastic increase in the 2 geochemical parameters had been observed, several days before the beginning of a significant increase in the seismic activity on the island. The increase in diffusive helium emissions continued over 2 more surveys, reaching a relative maximum of $30 \pm 2 \mathrm{kgd}^{-1}$ in October 6, several days before the occurrence of the submarine eruption. A significant decrease to $13 \mathrm{kgd}^{-}$ ${ }^{1}$ was estimated almost 10 days after the beginning of the eruption, followed by a sudden increase to 38 $\mathrm{kgd}^{-1}$ several days before the largest seismic event of the volcanic crisis $(M=4.6)$ occurred on November 11. On 5 March, the submarine eruption was over, but the volcanic process that started in mid-July 2011 had not finished. By the end of June 2012, a new seismic unrest episode occurred, accompanied by the highest deformation rate measured in the island during the unrest period. Within this phase, a new increase on the diffusive helium emission (up to $20 \mathrm{kgd}^{-1}$ ) was observed.

Figure $5 \mathrm{~b}$ depicts the evolution of the magmatic and crustal emission rate over the volcanic unrest period. The magmatic helium time series began with $<1 \mathrm{kgd}^{-1}$ and increased to $\sim 20 \mathrm{kgd}^{-1}$ several days before the eruption onset. However, the crustal helium emission remained at $\sim 1 \mathrm{kgd}^{-1}$ throughout the volcanic unrest period, except on the survey performed between 2 November and 8 November 2011, when it reached $12 \mathrm{~kg} / \mathrm{d}$ immediately before
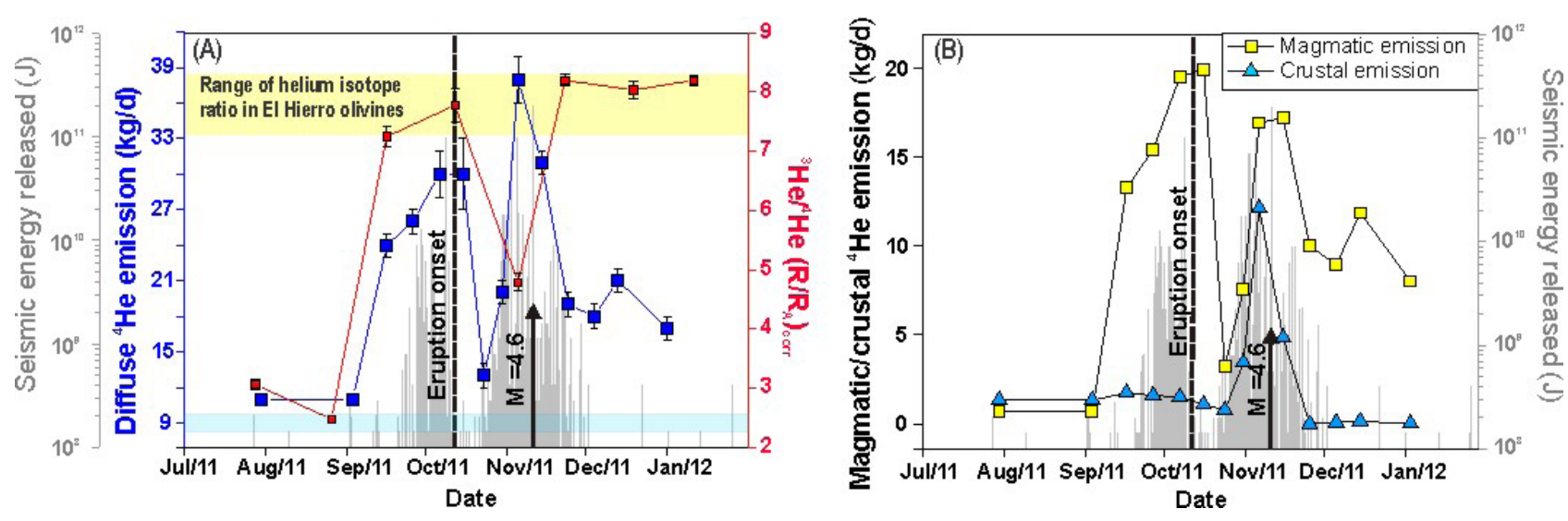

Figure 5. (a) Temporal evolution of seismic energy released (gray), diffusive helium emission at entire island (blue squares), and air-corrected ${ }^{3} \mathrm{He} /{ }^{4} \mathrm{He}$ ratio in San Simon groundwater (red squares). $\mathrm{R}_{\mathrm{A}}=$ atmospheric ${ }^{3} \mathrm{He} /{ }^{4} \mathrm{He}$ ratio. Errors on diffusive helium emission values are $1 \sigma$ of 50 equiprobable realizations by sequential Gaussian simulation. Yellow band represents range of ${ }^{3} \mathrm{He} /{ }^{4} \mathrm{He}$ ratios measured on olivine phenocrysts at El Hierro lavas, 7.2-8.2 $\mathrm{R}_{\mathrm{A}}$ (Day and Hilton, 2011). (b) Temporal evolution of estimated magmatic (yellow squares) and crustal (blue triangles) helium emission during volcano-seismic unrest and seismic energy released (gray bars). 


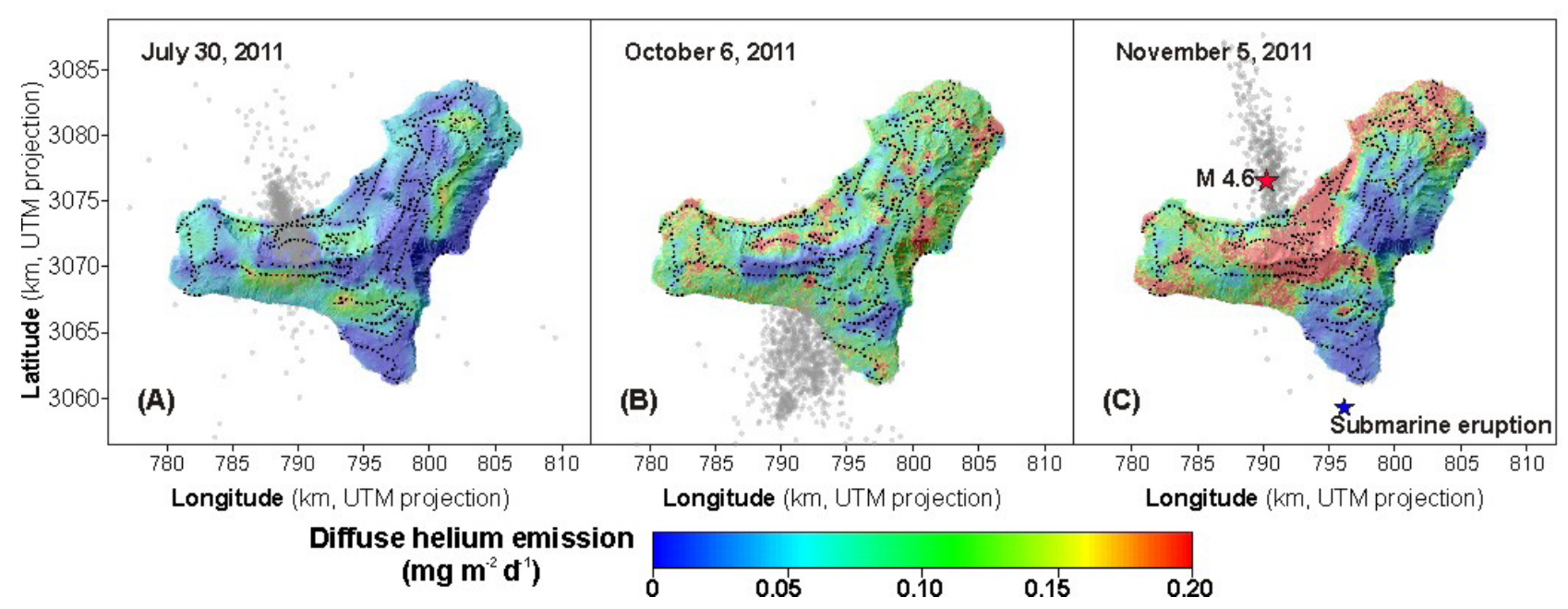

Figure 6. Spatial distribution of diffusive helium emission values (UTM-Universal Transverse Mercator.) Gray dots indicate seismicity in sampling period; black dots indicate sampling sites. A: Measured in first 2011 survey, 25 July through 4 August 2011. (b) Measured immediately before occurrence of submarine eruption, 2-10 October 2011. (c) Measured immediately before occurrence of largest earthquake of seismic-volcanic unrest period (M 4.6, red star), 2-8 November 2011. Blue star indicates location of submarine eruption.

the occurrence of the biggest earthquake of the unrest period. Figures $6 \mathrm{a}$ and $6 \mathrm{~b}$ reveal that the density of warm colors is higher prior to the eruption than at the beginning of the unrest period, indicating an increase in helium emissions from $11 \pm 1 \mathrm{kgd}^{-1}$ to $30 \pm 2 \mathrm{kgd}^{-1}$.

At the beginning of the seismic-volcanic unrest period, magma movement beneath El Hierro Island generated new fracture and microfracture systems, allowing volcanic gases to travel to the surface. Helium could easily ascend from deep areas through structures of high vertical permeability, thereby enhancing the helium content of soil gases. This fact was confirmed by an increase in the amount of mantle-derived gases dissolved in the San Simon waters exhibited by the ${ }^{3} \mathrm{He} /{ }^{4} \mathrm{He}$ ratio. The increases in the diffusive helium emission values over the entire island preceded episodes of seismic energy release. Similar results were observed by continuous monitoring of diffuse $\mathrm{CO}_{2}$ and $\mathrm{H}_{2} \mathrm{~S}$ emissions by using two different geochemical stations (Pérez et al., 2012). The onset of the submarine eruption produced a sudden release of volcanic gases, and consequently, a decrease in the volcanic gas pressure of the magma bodies moving beneath the island, reflected by a drastic decrease in the diffusive helium emissions measured between 20 and 26 October 2011.

These results clearly show the critical role that helium can play in the prediction of major volcanic events and the importance of continuous monitoring of this gas in active volcanic regions, mainly when magma migrates aseismically, i.e., silently, toward the surface.

\section{Diffuse $\mathrm{CO}_{2}$ emission surveys}

Since 1998, diffuse $\mathrm{CO}_{2}$ emission has been investigated at $\mathrm{El} \mathrm{Hierro} \mathrm{volcanic} \mathrm{system} \mathrm{in} \mathrm{a} \mathrm{yearly}$ basis during the summer periods (10 surveys). Since July 2011, and due to the start of the seismic-volcanic crisis at El Hierro, 19 diffuse $\mathrm{CO}_{2}$ emission surveys were undertaken until 25 March 2012 (Melián et al., 2014). The same sampling grid of 601 soil $\mathrm{CO}_{2}$ efflux measurements sites was repeated 29 times during the study period. The sampling grid was initially designed covering all the surface of El Hierro with site spacing about $400 \mathrm{~m}$ (Figure 7a). To warrant a correct location of the sampling sites, their coordinates were stored in a hand-sized GPS. The closed accumulation chamber method (Parkinson, 1981) was used to measure the $\mathrm{CO}_{2}$ efflux in all the 29 surveys. Measurements were carried out by means of a portable non-dispersive infrared $\mathrm{CO}_{2}$ analyzer LICOR-820 system, with a measurement range of 0-2000 ppmV (optical bench $14 \mathrm{~cm}$ ). The LICOR analyzer is interfaced to a hand size computer running the data acquisition software.

Soil $\mathrm{CO}_{2}$ efflux data were used to construct spatial distribution maps using sequential Gaussian simulation (sGs) provided by the sgsim program (Deutsch and Journel, 1998), which has been applied during recent years to soil $\mathrm{CO}_{2}$ diffuse degassing at many volcanic and geothermal sites. The final maps were always constructed as an average of 100 equiprobable realizations performed over a grid of 

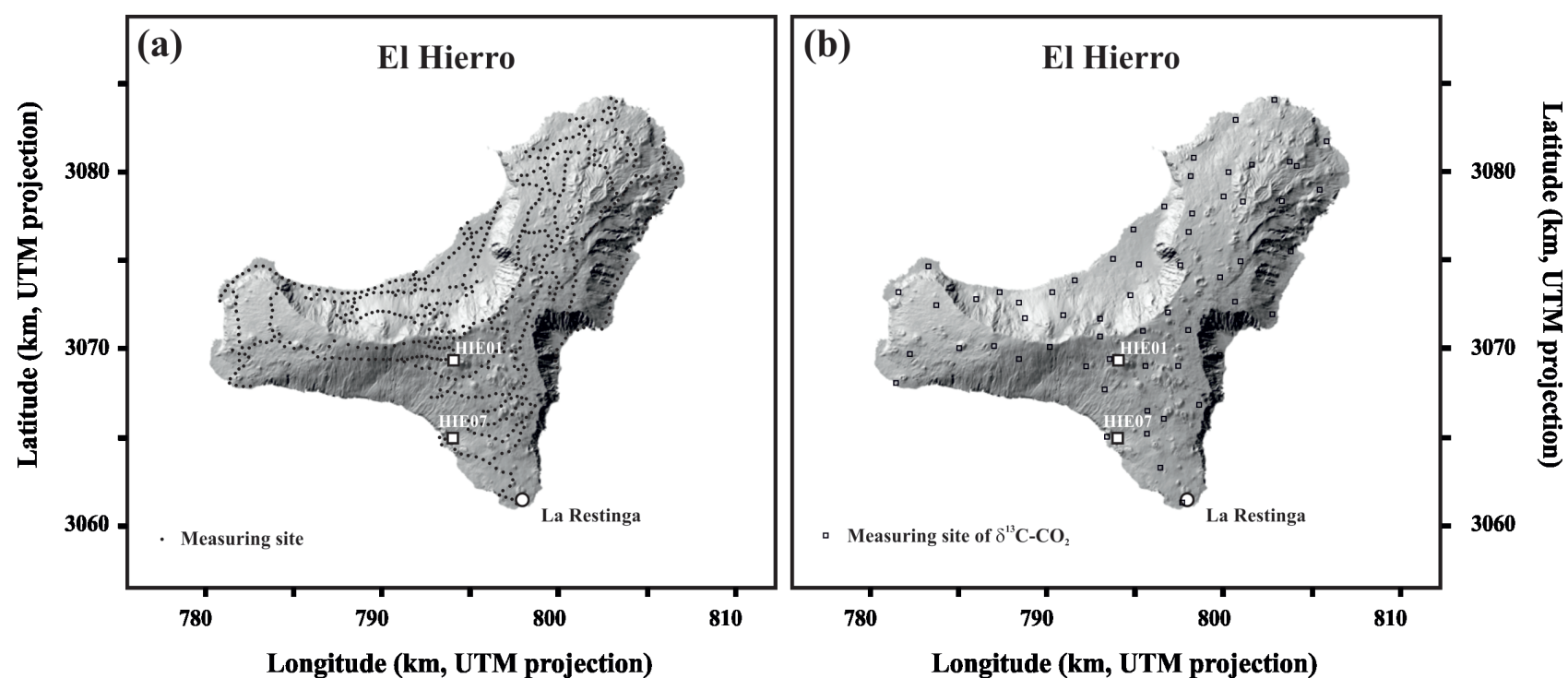

Figure 7. Location of (a) measurement sites (black dots) of diffuse $\mathrm{CO}_{2}$ efflux and (b) sampling sites for $\delta^{13} \mathrm{C}_{-} \mathrm{CO}_{2}$ and $\mathrm{CO}_{2}$ content analysis in the soil gases (open squares). The white square indicates the location of the geochemical stations HIE01 and HIE07.

27,999 squared cells $(100 \mathrm{~m} \times 100 \mathrm{~m})$ following the variogram model and the experimental variograms for the 29 surveys were fitted with spherical theoretical model (Melián et al., 2014). Since quantification of the uncertainty of the total $\mathrm{CO}_{2}$ is an important task for a correct interpretation of the temporal variations, the mean, and the standard deviation of the 100 simulated values of total $\mathrm{CO}_{2}$ output were assumed to be the characteristics values of the $\mathrm{CO}_{2}$ released and of its uncertainty (Cardellini et al., 2003).

To investigate the carbon isotopic composition of the soil $\mathrm{CO}_{2}, 60$ sampling sites were selected homogenously along the study area in 9 of the 29 surveys. The sampled sites selected to measure the carbon isotopic composition of the $\mathrm{CO}_{2}$ were the same in the 9 surveys, in order to minimize the effect caused by differences in the sampling grid (Figure $7 b$ ). Soil gas samples were collected at $40 \mathrm{~cm}$ depth using a metallic probe, stored in glass vials, and analyzed by means of a Thermo Finnigan MAT 253 isotope ratio mass spectrometer by continuous flow injection from a Finnigan GasBench II $\left(\delta^{13} \mathrm{C}\right.$ standard error $\pm 0.1 \%$ ).

Soil $\mathrm{CO}_{2}$ efflux values range from nondetectable $\left(\sim 0.5 \mathrm{gm}^{-2} \mathrm{~d}^{-1}\right)$ up to $457 \mathrm{gm}^{-2} \mathrm{~d}^{-1}$, with an average value of $3.5 \mathrm{gm}^{-2} \mathrm{~d}^{-1}$ during the entire study. The range of measured $\mathrm{CO}_{2}$ efflux values is similar to that observed at other volcanic systems of the Canaries (Hernández et al., 2012a; Padrón et al., 2008), and even though these values are lower than those measured in other active volcanic areas, the highest values can be explained as a mixture of biogenic and an endogenous source. Figure 8 shows 6 selected maps of the 29 based on the mean simulated total $\mathrm{CO}_{2}$ output value obtained for El Hierro between July 2011 and March 2012. During this study, soil $\mathrm{CO}_{2}$ efflux showed a large variability. The maps show that most of higher soil $\mathrm{CO}_{2}$ efflux values occur along the volcanic rifts of the island. These volcanic structures are characterized by a higher vertical permeability favoring endogenous gases rising to the surface. Vegetation at these areas (pine forest) might also contribute to the observed $\mathrm{CO}_{2}$ efflux values. In the other hand, lower values of $\mathrm{CO}_{2}$ effluxes are mainly observed along the edges of the investigated area (near the coast), where scarce vegetation exists. A visual inspection of these two maps reveals that the density of warm colors is higher during November 2011, just after the eruption onset and during the occurrence of the biggest earthquake of the unrest period, indicating the increase in $\mathrm{CO}_{2}$ emissions.

With the aim of evaluating the temporal evolution of the total diffuse soil $\mathrm{CO}_{2}$ emission from $\mathrm{El}$ Hierro volcanic system and its relationship with the seismic-volcanic activity, we have consider first the temporal evolution of the total diffuse $\mathrm{CO}_{2}$ emission in a quiescence period. Figure 9 shows the temporal evolution of the mean simulated values of yearly total $\mathrm{CO}_{2}$ outputs between 1998 and 2010, a year before the onset of anomalous seismic activity with the limits representing the one standard deviation of the cutoff mean value. In the period 1998-2010, diffuse $\mathrm{CO}_{2}$ 

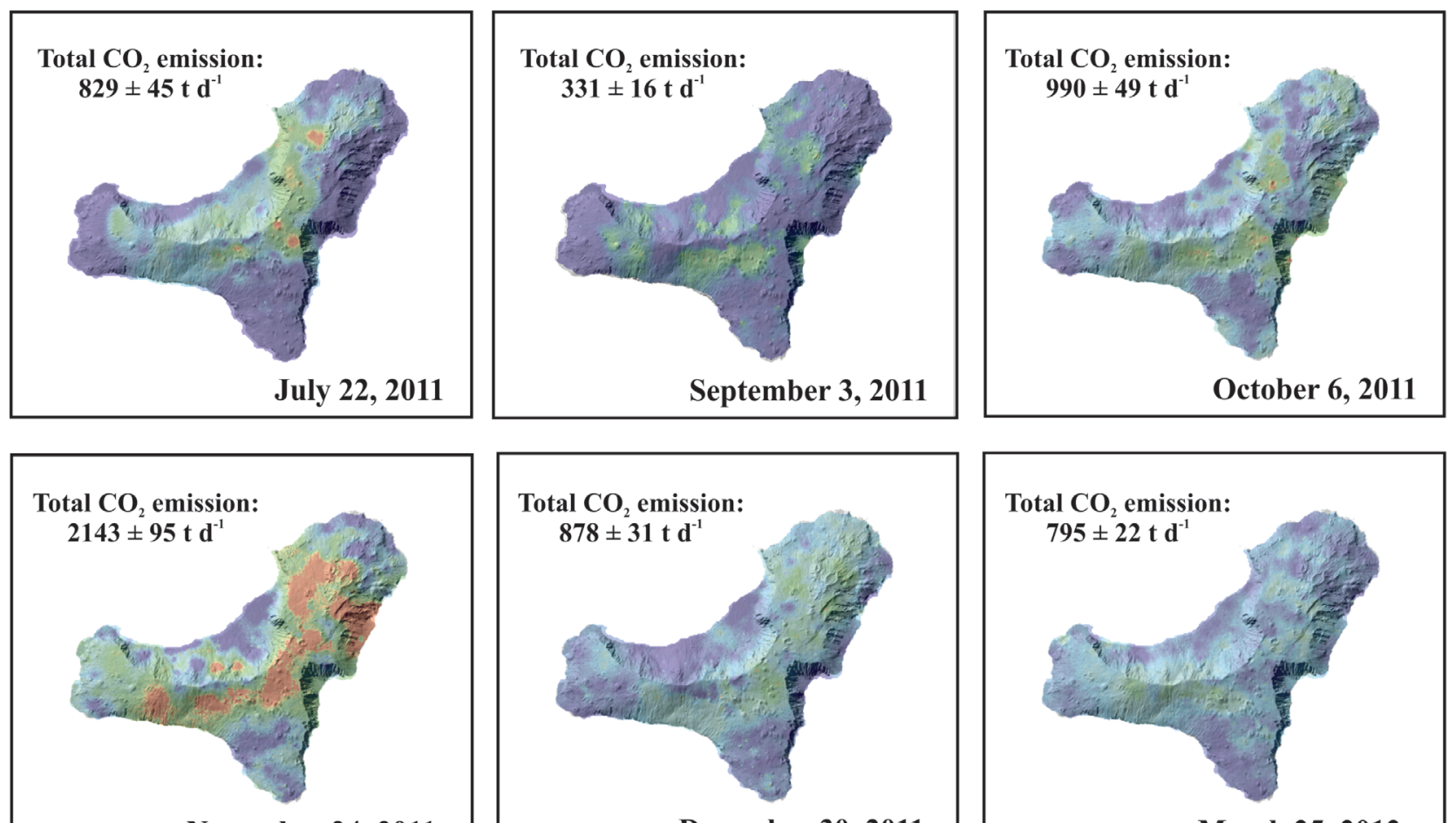

November 24, 2011
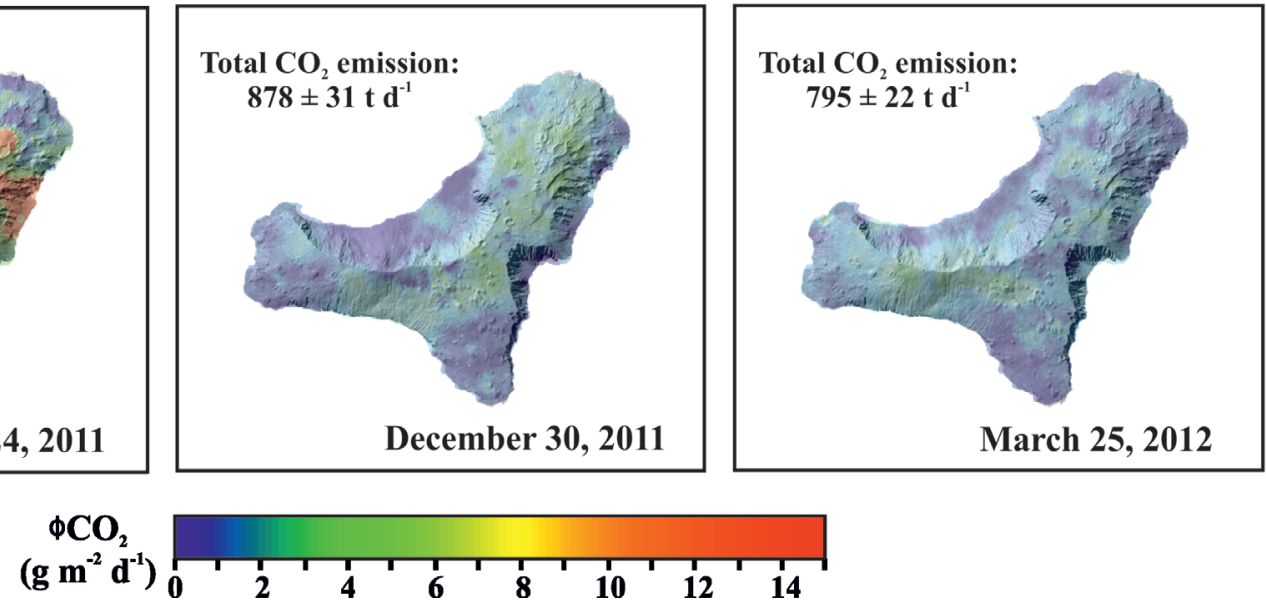

Figure 8. Selected soil $\mathrm{CO}_{2}$ efflux maps at El Hierro constructed from an average of 100 realizations using the sGs method.

emission showed a high variability (minimum value: $358 \mathrm{td}^{-1}$ in 2003 and maximum value: $1,434 \mathrm{td}^{-1}$ in 2004). The most remarkable characteristics of the temporal evolution in this period are the following: (i) The maximum emission value was observed in 2004 (higher than the cutoff background emission $+1 \sigma$ ), concurrently with the relative maximum of the seismicity in the period 1998-2010; (ii) The descending degassing pattern of the diffuse $\mathrm{CO}_{2}$

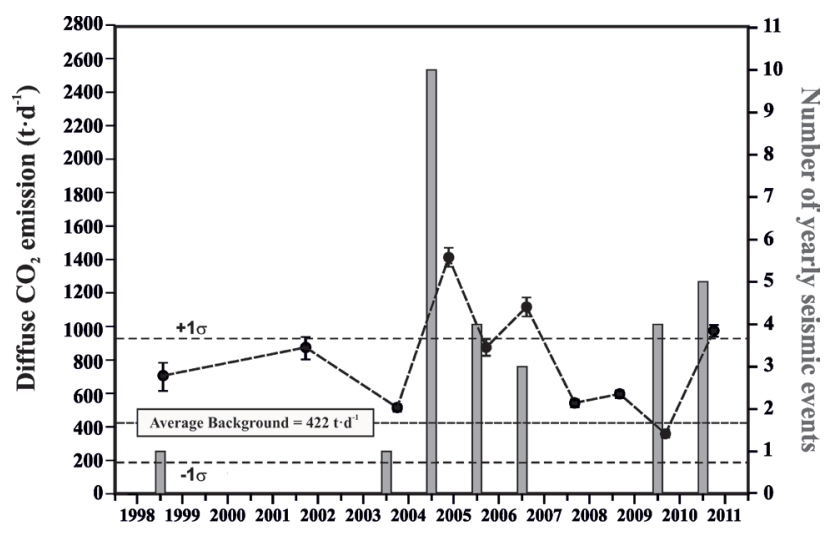

Figure 9. Temporal evolution of total diffuse $\mathrm{CO}_{2}$ emission rate for the 1998-2010 surveys at El Hierro and yearly number of seismic event in and around EL Hierro (source IGN). emission in the period 2004-2009, with an exception in 2006, changed significantly after the 2010 survey.

Figure 10 depicts a daily estimation between end of July 2011 and end of March 2012. Based on changes in emission trend and the geological process observed in the time series, we divided the time series in seven stages for the period July 2011 (beginning of the seismic-volcanic unrest) and March 2012 (end of the submarine eruption). The different phases observed prior to the submarine eruption are described as:

Phase A(21 July to 8 September 2011). It represents a decreasing trend on the diffuse $\mathrm{CO}_{2}$ emission from the start of the seismicity to 9 September (Figure 10), which was characterized by high earthquake rates and relatively low magnitudes, reflecting the initial intrusion of magma from the upper mantle into the crust (Phase 1 at Ibáñez et al. 2012). Estimated $\mathrm{CO}_{2}$ output values for this phase ranged from 378 to 938 $\mathrm{td}^{-1}$ (average $=627 \mathrm{td}^{-1}$ ) and were mostly always higher than the average background emission (422 td $^{-}$ $\left.{ }^{1}\right)$. Pérez et al., 2012, reported for the period 19 July to 10 August, soil $\mathrm{CO}_{2}$ efflux values characterized by a low variance and showing a median value of 5.6 


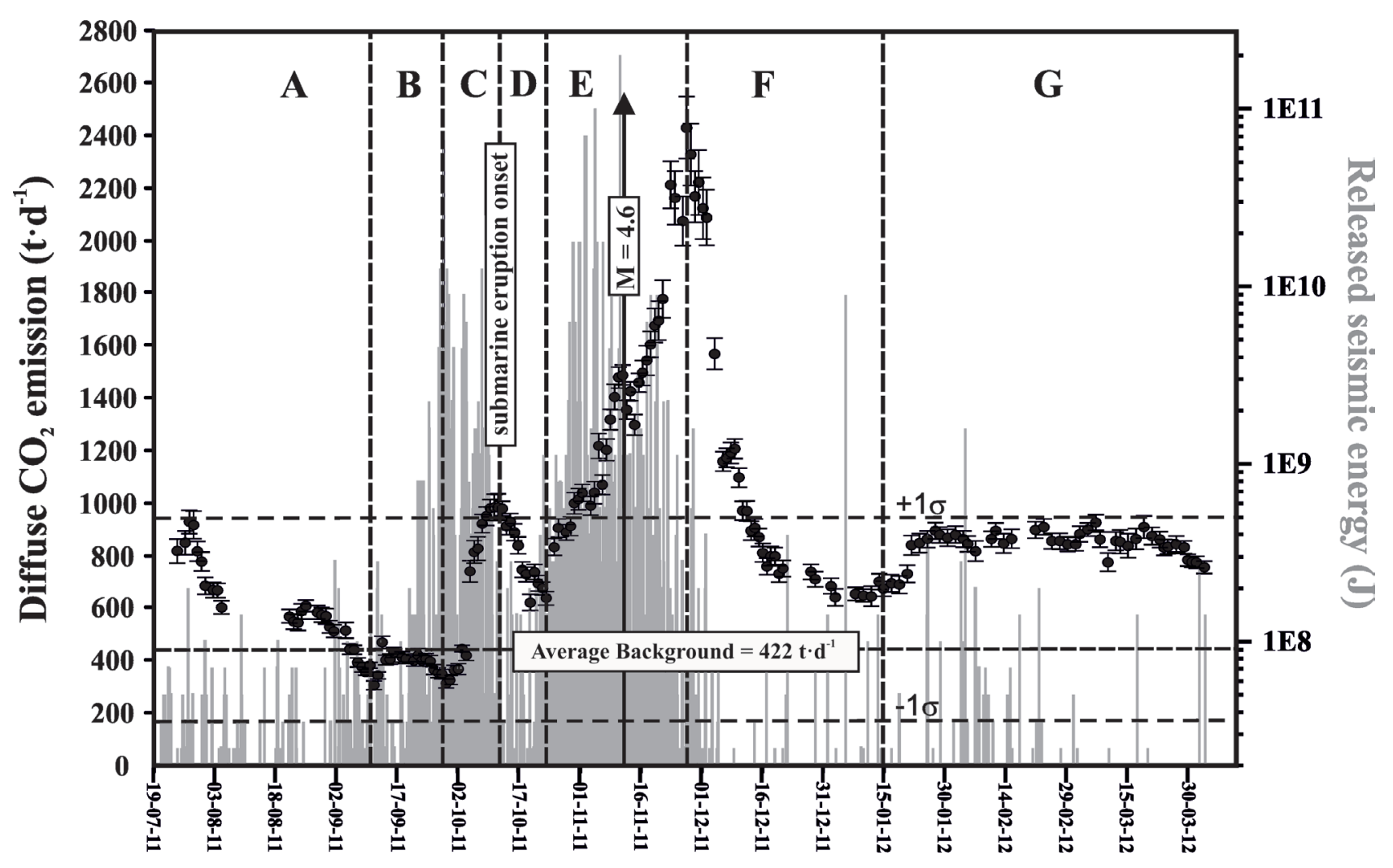

Figure 10. Temporal evolution of total diffuse $\mathrm{CO}_{2}$ emission rates for the period July 2011 to March 2012 and seismic energy released (light gray vertical bars, source IGN). Capital letters correspond to the adopted phases. Average background emission with $\pm \sigma$ is also shown.

$\mathrm{gm}^{-2} \mathrm{~d}^{-1}$ at the station HIE01, whereas Padrón et al., 2013, for the same period, reported diffusive helium emission values of $11 \pm 1 \mathrm{kd}^{-1}$, slightly higher than the background emission measured in 2003 (9 \pm 1 $\left.\mathrm{kd}^{-1}\right)$ as well as ${ }^{3} \mathrm{He} /{ }^{4} \mathrm{He}$ isotopic ratios of $2.48 \pm 0.07$ $\mathrm{R}_{\mathrm{A}}$ in groundwater. According to Sagiya et al., 2012, from the middle of July to middle of September, steady magmatic inflation occurred at the center of the island. The inflated volume of the first stage was estimated to be about $1.3 \times 107 \mathrm{~m}^{3}$ at the depth of about $5 \mathrm{~km}$. The absence of an ascending trend in the diffuse $\mathrm{CO}_{2}$ degassing is consistent with the above observations.

Phase B (between 9 and 28 September 2011). It represents a period of stability in the rate of $\mathrm{CO}_{2}$ emissions, with $\mathrm{CO}_{2}$ output values ranging from 331 to $490 \mathrm{td}^{-1}\left(\right.$ average $\left.=410 \mathrm{td}^{-1}\right)$ and was characterized by the occurrence of relatively low magnitude seismic events (Figure 10). The last 8 days of this period, coincide with the Phase 2 in Ibáñez et al. 2012 (21 September to 15 October 2011), when seismicity migrated to the south with an apparent ordinary tectonic activity. Since early September, a magmatic degassing process was observed by a continuous increase in the degassing rate measured in an automatic geochemical station at the center of the island (Pérez et al., 2012). By mid-September, the magmatic degassing process was reaffirmed by a drastic increase in the diffusive helium emission in the whole island and its magmatic fraction in groundwater (Padrón et al., 2013).These geochemical observations preceded the significant increment in the seismic activity (number and magnitude of the seismic events increased) registered after 20 September (Phase 2 in Ibáñez et al. 2012).

Phase C (29 September to 12 October 2011). It's characterized by a sharp increase in the rate of $\mathrm{CO}_{2}$ emissions (Figure 10), with $\mathrm{CO}_{2}$ output values ranging from 350 to $991 \mathrm{td}^{-1}$ (average $\left.=735 \mathrm{td}^{-1}\right)$. During this phase, the submarine eruption occurred (12 October) with a substantial lack of shallow seismicity between $8 \mathrm{~km}$ depth and the surface, probably because the magma found a preexisting fragile area, which would permit an aseismic migration toward the surface (Ibáñez et al., 2012). The observed increase on the $\mathrm{CO}_{2}$ emission started almost 2 weeks before the onset of the submarine eruption, reflecting a clear geochemical anomaly in 
$\mathrm{CO}_{2}$ emission, most likely due to increasing release of deep-seated magmatic gases to the surface, and coincides with a sharp increase in the soil $\mathrm{CO}_{2}$ efflux measured at HIE01 station (Pérez et al., 2012). During this phase, the increase in diffusive helium emission continued, reaching a relative maximum of $30 \pm 2 \mathrm{kd}^{-1}$, which also preceded the onset of the submarine eruption (Padrón et al., 2013). The ${ }^{3} \mathrm{He} /{ }^{4} \mathrm{He}$ ratio measured in groundwater also showed a relative maximum (Padrón et al., 2013). This period was also characterized by the accelerated deformation due to the upward as well as southward migration of magma (Sagiya et al., 2012). Additional inflation of about $2.1 \times 107 \mathrm{~m}^{3}$ occurred in the depth range of $1-2 \mathrm{~km}$. During this Phase, a ML 4.3 earthquake occurred on 8 October (4 days before the submarine volcanic eruption). Domínguez Cerdeña et al., 2014, pointed out that this earthquake did not trigger the magma ascent because magma velocity should have been too high. Our data support that magma was already ascending before the occurrence of the ML 4.3 earthquake as was suggested by Domínguez Cerdeña et al., 2014.

Phase D (13 October to 24 October 2011). It corresponds to a new decreasing trend on the diffuse $\mathrm{CO}_{2}$ emission after the onset of the submarine volcanic eruption (Figure 10). From 15 October, earthquake epicenters migrated north of the El Golfo area (Ibáñez et al., 2012) and location depths were deeper than during the period 19 July to 14 October, between 15 and $25 \mathrm{~km}$. Estimated $\mathrm{CO}_{2}$ output values for this period ranged from 638 to $937 \mathrm{td}^{-1}$ (average of $\left.777 \mathrm{td}^{-1}\right)$. This decrease on the $\mathrm{CO}_{2}$ emission occurred together with the decrease of soil $\mathrm{CO}_{2}$ efflux at HIE01 station (Pérez et al., 2012), and a decreasing in diffusive helium emission and ${ }^{3} \mathrm{He} /{ }^{4} \mathrm{He}$ ratio (Padrón et al., 2013), indicating a decrease in the volcanic gas pressure of the magma moving beneath the island, about 3 weeks after the first submarine eruption. During this stage, submarine eruption continued while no significant surface deformation was observed (Sagiya et al., 2012), indicating that magma supply from a deeper magma reservoir continued during this period.

Phase E. This phase, between 24 October and 27 November 2011, is characterized by a new sharp increase in the rate of $\mathrm{CO}_{2}$ emissions (Figure 10), reaching in 27 November the maximum $\mathrm{CO}_{2}$ output estimated value of all time series, $2.398 \mathrm{t} \mathrm{d}$ $1\left(\right.$ average $\left.=735 \mathrm{td}^{-1}\right)$. The observed $\mathrm{CO}_{2}$ emissions increase during this phase preceded an increment in the amplitude of the tremor signal and episodes of maximum degassing observed as vigorous bubbling at the sea surface in 3-7 November. The $\mathrm{CO}_{2}$ emissions increase continued reaching a relative maximum 1 day before the highest magnitude earthquake occurred in the studied period (ML 4.6). In late November 2011, a new input of fresh magma caused the start of a second eruptive episode. This observation might support the maximum $\mathrm{CO}_{2}$ degassing rate observed in El Hierro during the study period (27 November 2011). This increase on the diffuse $\mathrm{CO}_{2}$ emission was preceded by an increase of diffusive helium emission, reaching the absolute maximum of the series $\left(38 \pm 2 \mathrm{kgd}^{-1}\right)$ on the survey performed between 2 and 8 November (Padrón et al., 2013).

Phase F (28 November 2011 to 3 January 2012). It corresponds to a new decreasing trend on the diffuse $\mathrm{CO}_{2}$ emission after the maximum $\mathrm{CO}_{2}$ output observed (Figure 10). Estimated $\mathrm{CO}_{2}$ output values for this period ranged from 657 to $2,299 \mathrm{td}^{-1}$, with an average of $1,169 \mathrm{td}^{-1}$.

Phase G (15 January to 5 March 2012). It represents a new increase and stability in the rate of $\mathrm{CO}_{2}$ emissions, with $\mathrm{CO}_{2}$ output values ranging from 661 to $934 \mathrm{td}^{-1}$, with an average value of 834 $\mathrm{td}^{-1}$ (Figure 10). The end of this phase corresponds to the time when Scientific Committee stated that the submarine eruption was over (Smithsonian report, 29 February to 6 March 2012). Volume change in the magmatic reservoir observed by González et al., 2013, suggests the ascent of one or two more primitive magma pulses from an upper mantle source during January-February 2012, which is consistent with the slight new increase in the rate of $\mathrm{CO}_{2}$ emissions depicted in Figure 10.

Figure 11 combine the results obtained through continuous monitoring of the diffuse $\mathrm{CO}_{2}$ emission at HIE01 station reported by Pérez et al., 2012, with the discrete surveys described in this work. Both time series show a positive correlation $\left(\mathrm{r}^{2}=0.89\right)$ with a delay of 28 days in the discrete emission data. This correlation seems to be only apparent, because the higher peak in the HIE01 station should be related to the first increase in the survey emission (Phase C) and not to the Phase E. The bulk of the seismicity in Phase E was located off the northern coast of El Hierro (Phase 3 in Figure 2), which indicates that magma movements were occurring at the farthest site from HIE01 station of the study period. This 


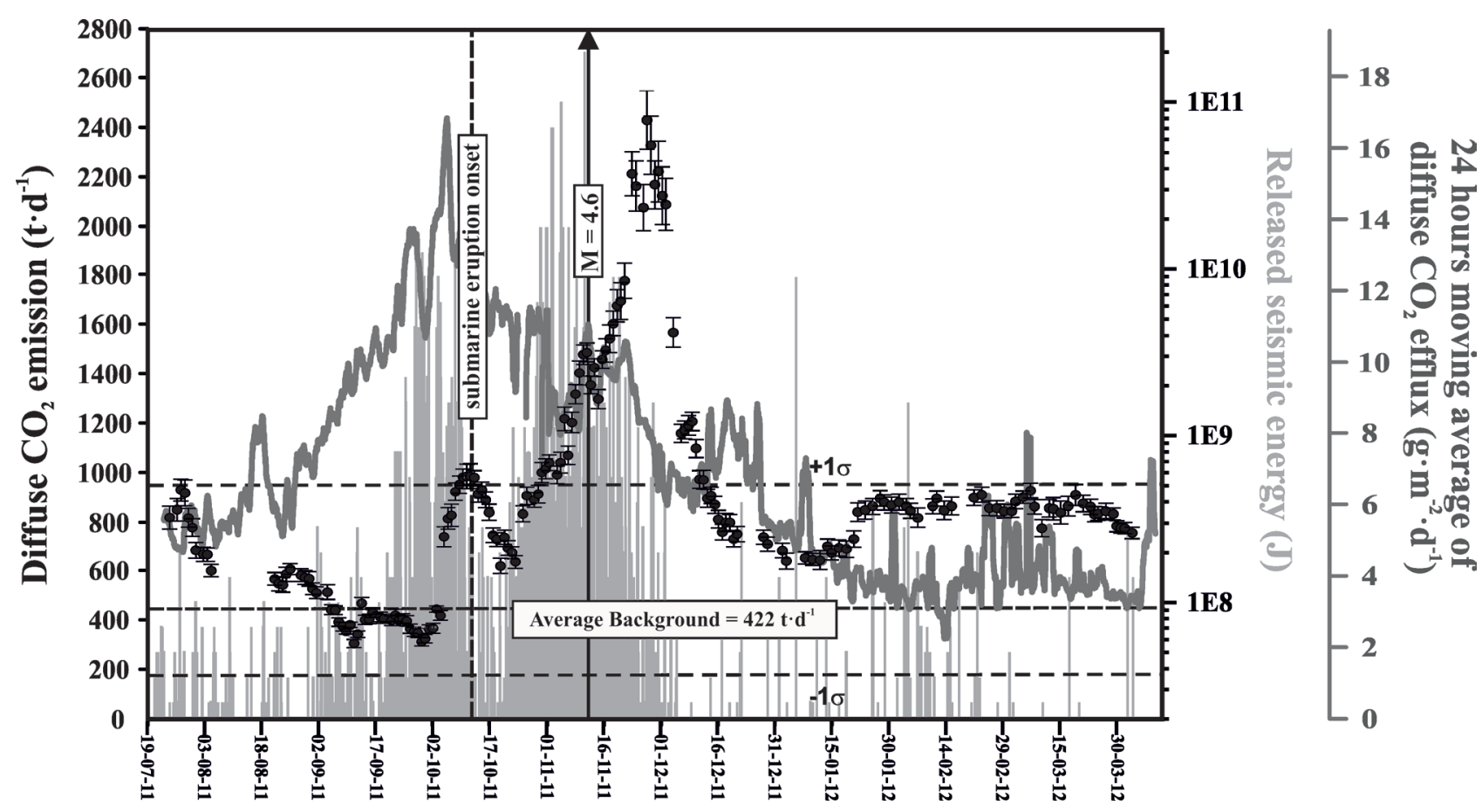

Figure 11. Time series of the $24 \mathrm{~h}$ moving average of diffuse $\mathrm{CO}_{2}$ efflux at HIE01 station reported by Pérez et al., 2012, and temporal evolution of total diffuse $\mathrm{CO}_{2}$ emission rate during 2011-2012. The seismic energy released recorded by the seismic network of IGN during the same time period is also shown.

disadvantage inherent to the study in a continuous mode is minimized in the discrete surveys carried out at El Hierro.

Soil gas samples collected in 2011 and 2012 showed a wide range of $\delta^{13} \mathrm{C}-\mathrm{CO}_{2}$ values (Melián et al., 2014). Figure 12 shows the correlation diagrams between the $1 / \mathrm{CO}_{2}$ content and $\delta^{13} \mathrm{C}_{-} \mathrm{CO}_{2}(\% 0)$ values in soil gas samples for 9 of the 29 survey Air, biogenic gas, and deep $\mathrm{CO}_{2}$ reservoirs were considered in the diagram. Most of the data plot in

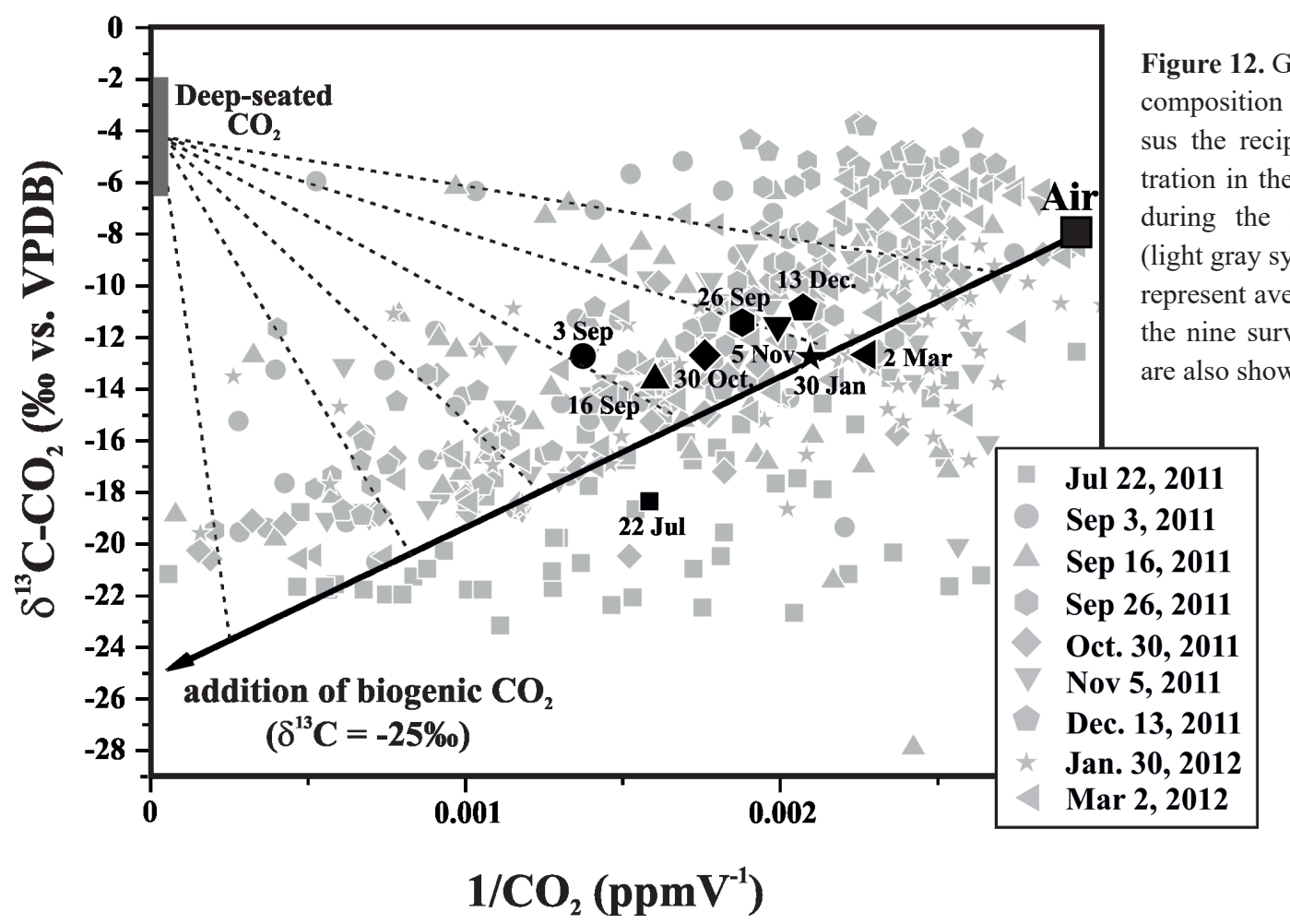


and around the line of addition of biogenic $\mathrm{CO}_{2}$, with points plotting along the mixing line of biogenic $\mathrm{CO}_{2}$ with atmospheric air. The isotopic data plotted out of the triangle made by the atmospheric, biogenic gas, and deep-seated $\mathrm{CO}_{2}$ end-members can be explained by an almost pure biogenic $\mathrm{CO}_{2}$ with concentrations slightly higher or similar to that of air. Although not significant, several points present an increase on the magmatic contribution. The $\mathrm{CO}_{2}$ increase observed in the fall-winter season of 2011-2012 does not seem to be driven mainly by an enhanced biogenic $\mathrm{CO}_{2}$ production in the soils of El Hierro, because the isotopic composition of the $\mathrm{CO}_{2}$ in the 5 November and 13 December samples did not follow the expected trend for a biogenic $\mathrm{CO}_{2}$ addition in Figure 12, suggesting other different origin (deep seated) for the gas. The dispersion of the $\mathrm{CO}_{2}$ efflux isotope compositions can be ascribed to the simultaneous occurrence of different processes such as the natural isotopic variability of the biogenic $\mathrm{CO}_{2}$ produced in the soils, the mixing of the biogenic $\mathrm{CO}_{2}$ with variable amounts of endogenous gas and the uncertainties of the method which are higher at low $\mathrm{CO}_{2}$ efflux values (Chiodini et al., 2008).

\section{THERMAL MONITORING}

Thermal images were collected by means of a hand-held FLIR Thermal Camera P65 during the eruptive period. The accuracy of the instrument (\% of reading) is $\pm 2{ }^{\circ} \mathrm{C}$ or $\pm 2 \%$. Erupted magma volumes were calculated from 19 October 2011 to 28 February 2012 by means of thermal imaging of a brown patch of warm seawater observed in front of La Restinga (Figure 13). During this period, we carried out thermal surveys every time we had the availability of a helicopter, allowing a total of 21 thermal surveys. Images were recorded taking care to avoid solar reflection (with cloudy weather) or at times of the day without direct sunlight (Pinkerton, James, \& Jones, 2002). Air temperature and humidity were measured in situ during every flight with a handheld digital thermometer-hygrometer before thermal image collection, and distance from the target was measured via the altimeter of the helicopter. Since

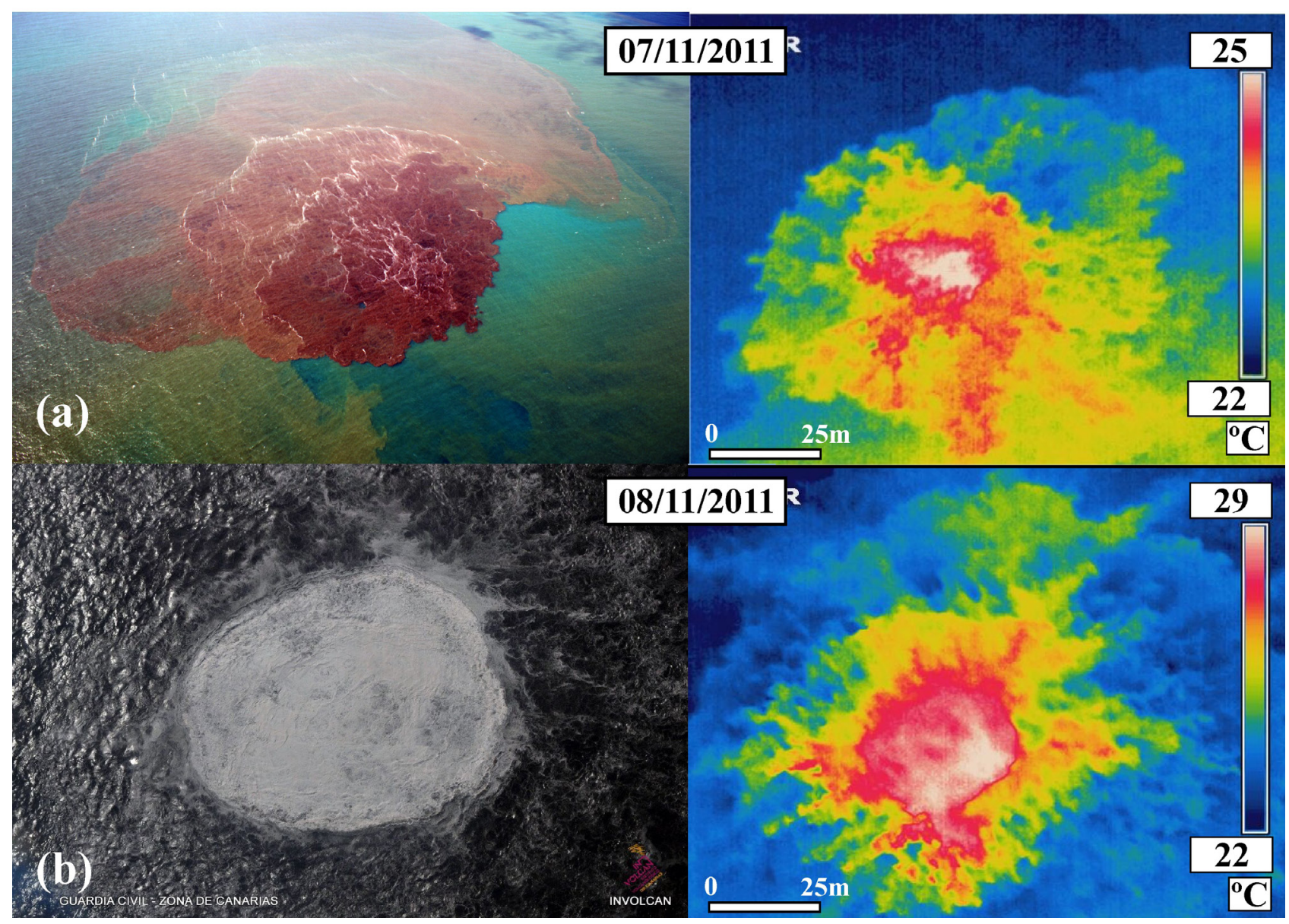

Figure 13. (a) Thermal infrared image of the discolored seawater area over the eruption site taken on November 7, 2011; (b) Thermal infrared image of the discolored seawater area over the eruption site taken on November 8, 2011. 
apparent temperatures are sensitive to viewing distance, thermal surveys from the helicopter were always carried out at three fixed altitudes over the eruption spot, $\sim 305, \sim 460$ and $\sim 610 \mathrm{~m}$. Thermal images of the sea surface were collected as perpendicular as possible to the sea surface in order to avoid atmospheric attenuation of source radiation (Spampinato et al., 2011).

The erupted volume of lava and pyroclastic was calculated on the basis of the temperature difference (heat flux exponential reduction) between the seawater contained within the dark patch visible at the sea surface $\left(\mathrm{T}_{\text {surface }}\right)$, and the boiling temperature of seawater next to the eruptive vent. After correction, maximum sea water temperatures within the discolored area ranged from $18.6{ }^{\circ} \mathrm{C}$ to $30.9{ }^{\circ} \mathrm{C}$, compared with sea surface temperature of $18-20{ }^{\circ} \mathrm{C}$ outside the eruption site. Maximum apparent temperatures obtained from thermal images of the sea surface showed interesting changes during the period of observation (Figure 14). The first and most important peak in Figure 14 was probably caused by strong emission of lava and release of hot hydrothermal fluids from the widening vent during the initial phase of the eruption. Eruptive activity between 5 and 10 November 2011 (Figure 13a and b) coincided with the occurrence of (i) large explosive "bubbles" at the sea surface, some potentially as high as $25 \mathrm{~m}$ on November 5, and (ii) the largest earthquake ( $\mathrm{M}=4.6)$ on November 11 (Ibáñez et al., 2012).

To estimate the erupted volume of lava flow and pyroclastic, we measured the surface area of heated seawater, depth of the submarine volcanic cone (lava effusion spot) and temperature of seawater not affected

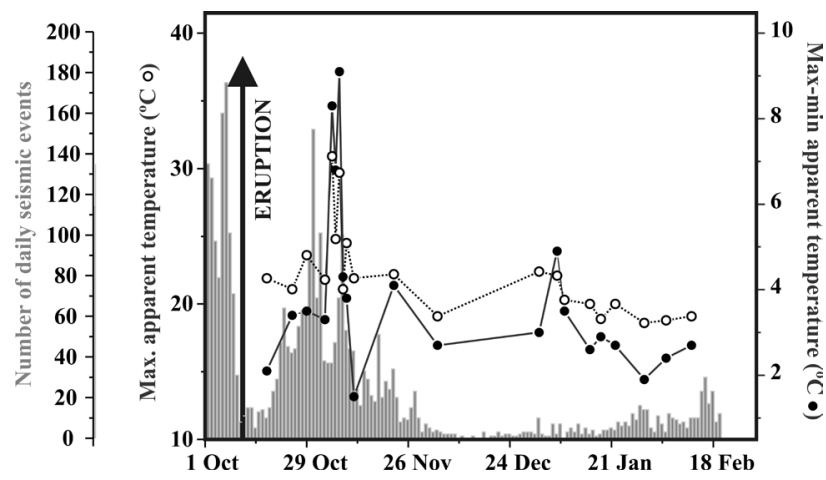

Figure 14. Temporal evolution of maximum apparent temperatures (open circles) and difference between maximum and minimum apparent temperatures (black circles) measured at the seawater surface. Daily seismic events are indicated with light gray bars (source IGN). by the eruption. For the 21 thermal infrared surveys, pixels containing temperatures that exceeded normal seawater temperatures were selected, allowing us to calculate the area of anomalous heating. Figure 13a shows a thermal infrared image of the seawater surface at the eruption site, taken on November 11 2011, a few days after the onset of the submarine volcanic activity. After computing total seawater volumes and depths of the submarine volcanic cone, Eq. (2) in Hernández et al., 2014, was used to estimate the daily erupted volumes.

Figure 15 shows the estimated erupted volumes for the 21 thermal surveys. In order to reconstruct the submarine eruptive thermal behavior and estimate the total erupted volume, a graphical interpolation was done between each survey, to obtain the cumulative erupted magma volume (black line in Figure 15). On this basis we obtained a total erupted volume of lava flows and pyroclastic of $300 \times 10^{6} \mathrm{~m}^{3}$ during the period of study (October 18, 2011-February 12, 2012), resulting in a TADR of $\sim 25 \mathrm{~m}^{3} \mathrm{~s}^{-1}$. This volume, although roughly estimated, is very close to the total accumulated volume of $329 \times 10^{6}$ non-dense rock equivalent $\mathrm{m}^{3}$ estimated by the IEO using bathymetric surveys (Rivera et al., 2013). These similar volume estimations suggest that the lava flows that erupted during the submarine eruption at El Hierro were very fluid due to their composition and most of the heat released was used to heat the surrounding seawater (Applegarth et al., 2010). Figure 15 displays two mean peaks in the curve of the erupted volume. The first peak was recorded at the start of the survey on

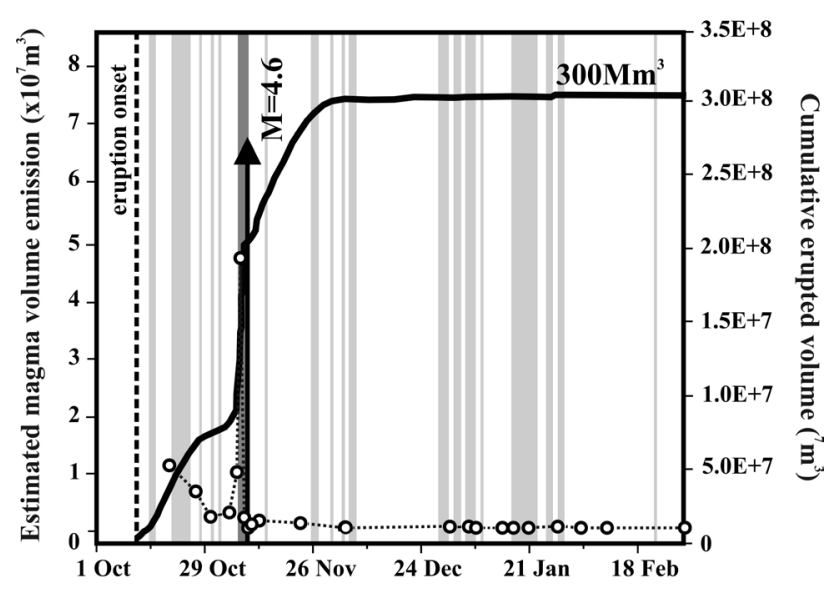

Figure 15. Temporal evolution of estimated magma volume emission (white circles) and cumulative erupted volume (solid black line) during the period of study. Light gray bars indicate formation of a patch with brown color and floating rocks. The dark gray bar indicates the days with stronger eruptive activity (bubbling columns at the sea surface). 
October 18, six days after eruption onset and due to the intense explosive activity during the early stages of the eruption; with a maximum of $\sim 152 \times 10^{6} \mathrm{~m}^{3}$ erupted magma averaged over $24 \mathrm{~h}$ on October 19 , 2011. The thermal measurement reached a climax between 5 and 7 November 2011, corresponding to a maximum of $\sim 656 \times 106 \mathrm{~m}^{3}$ erupted magma averaged over $24 \mathrm{~h}$ on November 7, 2011. The maximum erupted magma volume is very close to the peak volcanic tremor, suggesting that it was produced by both strong explosive activity, building up a submarine cinder cone, and vigorous lava output, typically recorded during the initial phases of fissure eruptions (Calvari et al., 2005, 2010; Harris et al., 2011).

The 2011-2012 submarine eruption at El Hierro has been a unique opportunity to monitor for the first time the volume of lava spreading over the sea bottom on the basis of thermal data collected from a helicopter. Our thermal data, together with seismicity and visual observations, have allowed us to reconstruct the temporal evolution of the eruption and to estimate the total magma volume emitted during the submarine eruption.

\section{ACKNOWLEDGEMENTS}

Thisresearch waspartially supported by the projects (i) MAKAVOL $(\mathrm{MAC} / 3 / \mathrm{C} 161)$ of the European Union Transnational Cooperation Programme MAC 2007-2013, (ii) ALERTA (MAC/2.3/C56) and ALERTA II (03/MAC/4.1/C6) of the European Union Transnational Cooperation Programme INTERREG III B Azores-Madeira-Canary Islands 2000-2006, (iii) EPHESTOS (CGL2011-29499-C02-01) of the Spanish National R+D+I Plan 2008-2011, and (iv) HELIO (ProID20100158) of the Canary Islands Agency for Research, Innovation and Information Society. I am also grateful to the Water Community of San Simón as well as to the Cabildo Insular de El Hierro and Cabildo Insular de Tenerife for their support. The author is also grateful to M.D. Peraza, M. Cordero, D. Machín, D. Rodríguez, V. Luis, J. León, J.A. León, C. Guzmán, S. Bobadilla, V. Montelongo, M. García, F. León, A. Díaz, C. Tapia, N. Herrero, L. Marrero, A.A. López, J. Carrillo, D.E. Nóbrega, C. Quevedo, C. Fernández, G. Funes, and W. De Fuentes for their help during the field work. Finally, the author is also grateful to the staff of El Hierro airport (AENA) for providing logistical support. The author acknowledge the tremendous help of UATF crews during the flights. Memoriam: Lieutenant Marcos Antonio BENITO, Helicopter Pilot Unit, UALEON, dead in act of service in august 2014.

\section{References}

Applegarth, L.J., Pinkerton, H., James, M.R., \& Calvari, S. (2010). Lava flow superposition: The reactivation of flow units in compound flow fields. J. Volcanol. Geotherm. Res. 194, 100-106.

Calvari, S., Spampinato, L., Lodato, L., Harris, A J.L., Patrick, M.R., Dehn, J., et al. (2005). Chronology and complex volcanic processes during the 2002-2003 flank eruption at Stromboli volcano (Italy) reconstructed from direct observations and surveys with a handheld thermal camera. J. Geophys. Res. 110, B02201.

Calvari, S., Lodato, L., Steffke, A., Cristaldi, A., Harris, A.J.L., Spampinato, L., et al. (2010). The 2007 Stromboli flank eruption: chronology of the events, and effusion rate measurements from thermal images and satellite data. J. Geophys. Res. 115(B4), B04201.

Cardellini, C., Chiodini, G., and Frondini, F. (2003). Application of stochastic simulation to $\mathrm{CO}_{2}$ flux from soil: Mapping and quantification of gas release, J. Geophys. Res. 108(B9), 2425. doi:10.1029/2002JB002165.

Chiodini, G., Caliro, S., Cardellini, C., Avino, R., Granieri D., and Schmidt, A. (2008).Carbon isotopic composition of soil $\mathrm{CO}_{2}$ efflux, a powerful method to discriminate different sources feeding soil $\mathrm{CO}_{2}$ degassing in volcanic-hydrothermal areas. Earth Planet. Sci. Lett. 274, 372-379.

Deutsch, C., and Journel, A. (1998). GSLIB: Geostatistical Software Library 740 and Users Guide, 2nd ed., Oxford Univ. Press, New York.

Domínguez Cerdeña, I., del Fresno, C., and Gomis Moreno, A. (2014). Seismicity patterns prior to the 2011 El Hierro eruption. Bull. Seismol. Soc. Am. 104(1), 567-575, doi:10.1785/0120130200.

García-Yeguas, A., Ibáñez, J.M., Koulakov, I., Jakovlev, A., Romero-Ruiz, M.C., Prudencio, J. (2014). Seismic tomography model reveals mantle magma sources of recent volcanic activity at El Hierro Island (Canary Islands, Spain). Geophys. J. Int. 199(3):1739-1750. doi:10.1093/gji/ggu339.

Gerlach, T.M., and Graeber E.J. (1985). Volatile budget of Kilauea volcano. Nature. 313(6000), 273-277, doi:10.1038/313273a0.

González, P.J., Samsonov, S.V., Pepe, S., Tiampo, K.F., Tizzani, P., Casu, F., Fernández, J., Camacho, A.G., and Sansosti, E. (2013). Magma storage and migration associated with the 2011-2012 El Hierro eruption: Implications for crustal magmatic systems at oceanic island volcanoes. J. Geophys. Res. Solid Earth. 118, 4361-4377, doi:10.1002/jgrb.50289.

Granieri, D., Carapezza, M.L., Chiodini, G., Avino, R., Caliro, S., Ranaldi, M., Ricci, T., and Tarchini, L. (2006). Correlated increase in $\mathrm{CO}_{2}$ fumarolic content and diffuse emission from La Fossa crater (Vulcano, Italy): Evidence of volcanic unrest or increasing gas release from a stationary deep magma body? Geophys. Res. Lett. 33, L13316, doi:10.1029/2006GL026460. Guillou, H., Carracedo, J.C., Pérez-Torrado, F., and Rodríguez Badiola, E. (1996). K-Ar ages and magnetic stratigraphy of 
a hotspot-induced, fast grown oceanic island: El Hierro, Canary Islands. J. Volcanol. Geotherm. Res. 73, 141-155, doi:10.1016/0377-0273(96)00021-2.

Harris, A.J.L., Steffke, A., Calvari, S., \& Spampinato, L. (2011). Thirty years of satellite derived lava discharge rates at Etna: Implications for steady volumetric output. J. Geophys. Res. 116, B08204.

Hernández, P.A., Notsu, K., Salazar, J.M., Mori, T., Natale, G., Okada, H., Virgili, G., Shimoike, Y., Sato, M., and Pérez, N.M. (2001). Carbon dioxide degassing by advective flow from Usu volcano, Japan. Science. 292, 83-86, doi:10.1126/ science. 1058450.

Hernández P.A., Padilla G., Padrón E., Pérez N.M., Calvo D., Nolasco D., Melián G., Barrancos J., Dionis S., Rodríguez F. and Sumino H. (2012). Analysis of long- and short-term temporal variations of the diffuse $\mathrm{CO}_{2}$ emission from Timanfaya volcano, Lanzarote, Canary Islands. Appl. Geochem. 27(12), 2486-2499, dio:10.1016/j.apgeochem.2012.08.008.

Hernández, P.A., Calvari, S., Ramos, A., Pérez, N.M., Márquez, A., Quevedo, R., Barrancos, R., Padrón, E., Padilla, G., López, D., Rodríguez Santana, A., Melián, G.V., Dionis, S., Rodríguez, F., Calvo, D., Spampinato, L. (2014). Magma emission rates from shallow submarine eruptions using airborne thermal imaging. Remote Sensing Environ. 154 (2014) 219-225. DOI: 10.1016/j.rse.2014.08.027.

Hernández Pacheco, A. (1982). Sobre una posible erupción en 1793 en la isla de El Hierro (Canarias). Est. Geológicos, 38, $15-25$.

Ibáñez, J.M., De Angelis, S., Díaz-Moreno, Hernández, P.A., Alguacil, G., Posadas, A., Pérez, N. (2012). Insights into the 2011-2012 submarine eruption off the coast of El Hierro (Canary Islands, Spain) from statistical analyses of earthquake activity. Geophys. J. Int. 191:659-670. doi:10.1111/j.1365246X.2012.05629.x

Masson, D.G. (1996). Catastrophic collapse of the volcanic island of Hierro $15 \mathrm{ka}$ ago and the history of landslides in the Canary Islands, Geol. Soc. Am. 24(3), 231-234, doi:10.1130/00917613(1996).

Melián, G., Hernández, P.A., Padrón, E, Pérez, N.M., Barrancos, J., Padilla, G., Dionis, S., Rodríguez, F., Calvo, D., Nolasco, D. (2014). Spatial and temporal variations of diffuse $\mathrm{CO}_{2}$ degassing at El Hierro volcanic system: relation to the 2011-2012 submarine eruption. J. Geophys. Res. Solid Earth. 119:6976-6991. doi:10.1002/2014JB011013.

Padilla, G., Hernández, P.A., Padrón, E., Barrancos, J., Pérez, N.M., Melián, G., Nolasco, D., Dionis, S., Rodríguez, F., Calvo, D., Hernández, I. (2013). Soil gas radon emissions and volcanic activity at El Hierro (Canary Islands): the 2011-2012 submarine eruption. Geochem. Geophys. Geosys. 14(2):432/447. doi:10.1029/2012GC004375.

Padrón E., Melián G., Marrero R., Nolasco D., Barrancos J., Padilla G., Hernández P. A. and Pérez N. M. (2008). Changes on diffuse $\mathrm{CO}_{2}$ emission and relation to seismic activity in and around El Hierro, Canary Islands. Pure App. Geophys., Special Issue "Terrestrial Fluids, Earthquakes and Vol-canoes: The Hiroshi Wakita vol. III”. 165, 95-114.

Padrón, E., Pérez, N.M., Hernández, P.A., Sumino, H., Melián, G., Barrancos, J., Nolasco, D., Padilla, G., Dionis, S.,
Rodríguez, F., Hernández, I., Calvo, D., Peraza, M.D., Nagao, K. (2013). Diffusive helium emissions as a precursory sign of volcanic unrest. Geology. doi:10.1130/G34027.1.

Parkinson, K.J. (1981). An improved method for measuring soil respiration in the field, J. Appl. Ecol. 18, 221-228.

Pérez, N.M., Padilla, G., Padrón, E., Hernández, P.A., Melián, G., Barrancos, J., Dionis, S., Nolasco, D., Rodríguez, F., Calvo, D., Hernández, I. (2012). Precursory diffuse $\mathrm{CO}_{2}$ and $\mathrm{H}_{2} \mathrm{~S}$ emission signatures of the 2011-2012 El Hierro submarine eruption, Canary Islands. Geophys. Res. Lett. 39:L16311. doi:10.1029/2012GL052410.

Pinkerton, H., James, M., \& Jones, A. (2002). Surface temperature measurements of active lava flows on Kilauea Volcano, Hawaii. J. Volcanol. Geotherm. Res. 113, 159-176.

Rivera, J., Lastras, G., Canals, M., Acosta, J., Arrese, B., Hermida, N., et al. (2013). Construction of an oceanic island: Insights from the El Hierro (Canary Islands) 2011-2012 submarine volcanic eruption. Geology. 41, 355-358.

Romero, C., and Guillén, C. (2012). New historical data about the volcanism from El Hierro, MAKAVOL 1ST Anniversary International Conference Commemorating the 2011-2012 El Hierro Submarine Eruption, October 10-15, El Hierro, Canary Islands, Spain.

Sagiya, T., Barrancos, J., Calvo, D., Padrón, E., Padilla, G., Hernández, P.A., Pérez, N.M. (2012). Crustal Deformation During the 2011 Volcanic Crisis of El Hierro, Canary Islands, Revealed by Continuous GPS Observation EGU Reference Shelf, 14, EGU.

Smith, D.K., Cann, J.R. (1992) The role of seamount volcanism in crustal construction at the Mid-Atlantic Ridge $\left(24^{\circ}-30^{\circ} \mathrm{N}\right)$. J. Geophys. Res. 97:1,645-1,658. doi:10.1029/91JB02507.

Smith, D.K., Jordan, T.H. (1987). Seamount statistics in the Pacific Ocean. J. Geophys. Res. 93(2):899-2,918. doi:10.1029/ JB093iB04p02899.

Spampinato, L., Calvari, S., Oppenheimer, C., \& Boschi, E. (2011). Volcano surveillance using infrared cameras. EarthScience Reviews. 106, 63-91.

Stroncik, N.A., Klügel, A., and Hansteen, T.H. (2009). The magmatic plumbing system beneath El Hierro (Canary Islands): constraints from phenocrysts and naturally quenched basaltic glasses in submarine rocks. Contrib. Mineral. Petrol. 157, 593-607, doi:10.1007/s00410-008-0354-5.

Sumino, H., Nagao, K., Notsu, K. (2001). Highly sensitive and precise measurement of helium isotopes using a mass spectrometer with double collector system. J. Mass Spectrom. Soc. Jpn. 49, 61-68. 